\title{
Naunyn-Schmiedeberg's Archives of Pharmacology under new editorship: change and continuity
}

\author{
Roland Seifert ${ }^{1}$
}

Received: 17 May 2016 / Accepted: 19 May 2016/Published online: 24 May 2016

(C) Springer-Verlag Berlin Heidelberg 2016

Effective July 1, 2016, I will become the Editor-in-Chief of Naunyn-Schmiedeberg's Archives of Pharmacology, the oldest existing pharmacological journal founded in 1873 (Starke 1998) as successor of Prof. Dr. Martin Michel, who has steered the journal since 2002. I would like to cordially thank Martin for his dedicated and outstanding service to the journal. Martin has served in various functions for NaunynSchmiedeberg's Archives of Pharmacology without interruption since 1994 and will continue as Associate Editor.

Under Martin's direction, Naunyn-Schmiedeberg's Archives of Pharmacology has prospered: The number of submissions to the journal has doubled since 2005. This is remarkable in light of the fact that several other traditional pharmacology journals are suffering decreases in their submissions, a development that is in part due to the competition by new open-access journals and many specialized journals covering one aspect or another of pharmacology. However, this increase in submission has neither resulted in an inflation of the content nor quality of Naunyn-Schmiedeberg's Archives of Pharmacology. This is reflected by a current manuscript acceptance rate of $39 \%$ that is similar to the rates of other leading pharmacology journals.

Naunyn-Schmiedeberg's Archives of Pharmacology has become a fast journal with a 26-day interval from submission to the first decision in 2015. Once accepted, publication occurs fast, and the online-first publication ensures rapid dissemination of an article in the scientific community before a print issue has been determined. The journal now also features an

Roland Seifert

seifert.roland@mh-hannover.de

1 Institute of Pharmacology, Hannover Medical School, Carl-Neuberg-Straße 1, 30625 Hannover, Germany open access-option for authors, broadening exposure of a paper to the scientific community. However, even without the open-access option, the journal is available in almost 10,000 institutions worldwide.

Under Martin's leadership, the journal has become truly international with submissions from more than 30 countries in 2015. In 2015, the countries with the most publications were Germany $>$ Egypt $>$ China $>$ Poland $>$ Brazil $>$ India $>$ Japan. The increasing internationality of the journal is also being reflected by the composition of the Editorial Board and the Editorial Advisory Board. Members of these two boards contributed very substantially to the high quality of the journal, also reflected by a stable impact factor of around 2.5. I wish to thank our board members for their excellent service to the journal.

Martin introduced several new features into the journal such as theme issues (Gomsyan and Szallasi 2015; Hsu et al. 2015), comprehensive non-clinical single compound reviews (Modjtahedi et al. 2014; Michel et al. 2015a), editorials (Michel et al. 2015b; Schneider et al. 2015; Seifert 2015a), debates (Seifert 2014; Gao and Vanhoutte 2014), letters to the editor (Michel-Reher and Michel 2015), and meeting reports (Friebe et al. 2015; Heifetz et al. 2015; Schneider and Seifert 2015), stimulating scientific exchange. Papers in these sections are downloaded very frequently. In the field of validation of receptor antibodies, Naunyn-Schmiedeberg's Archives of Pharmacology has earned exceptionally high international recognition and constitutes the leading international discussion forum on this important topic (Beermann et al. 2012; Böhmer et al. 2014; Ashton et al. 2014; Cécyre et al. 2014; Cernecka et al. 2014; Tripathi et al. 2016).

Pharmacology has always changed in terms of methods and research topics, but the chemical compound, be it an experimental tool, a drug candidate, or a clinically approved drug, has always been in the center. This will continue to be 
the case for pharmacology as academic discipline and the mission of the journal. At the turn of the millennium, Naunyn-Schmiedeberg's Archives of Pharmacology had a focus on biogenic amines, particularly adrenoceptors and serotonin receptors. Over the years, the topics covered in NaunynSchmiedeberg's Archives of Pharmacology have become more diverse, cancer pharmacology (Modjtahedi et al. 2014; Cheng et al. 2015), immunopharmacology (Merzoug et al. 2014; Cheng et al. 2015, Imeri et al. 2015), and pharmacology of natural compounds (Cheng et al. 2015) being important current themes. I will continue to welcome papers from these fields, but for natural compound studies, rigorous chemical characterization of ingredients and, within reasonable means, testing of identified lead compounds are mandatory (Michel et al. 2005).

With my own expertise in the field of molecular and cellular signal transduction, encompassing G-proteincoupled receptors, G-proteins, and second messenger systems, specifically cyclic nucleotides (for review, see, e.g., Seifert and Wenzel-Seifert 2002; Gille and Seifert 2004; Seifert et al. 2012; Seifert 2015b; Strasser et al. 2015), I would be pleased to receive papers from these areas. I myself have published numerous original papers in these areas in NaunynSchmiedeberg's Archives of Pharmacology during recent years (see, e.g., Bräunig et al. 2014; Laue et al. 2014; Wolter et al. 2014; Werner et al. 2016a, b; Reinartz et al. 2015a, b). Two of these papers (Bräunig et al. 2014; Wolter et al. 2014) contributed to discussions on controversial literature data and the importance of proper statistics in pharmacology (Seifert 2014; Gao and Vanhoutte 2014; Motulsky 2014b).

Martin is handing over to me the journal in such an excellent state and with such dedicated Editorial Board and Editorial Advisory Board that no revolution in running the journal will occur, but evolution will take place: Since nonreproducibility of data is a big issue (Kannt and Wieland 2016), we will foster high standards in terms of statistics (Michel 2014; Motulsky 2014a). Related to this, I will consider papers that corroborate or confirm important hypotheses in pharmacology, and solid papers on failed attempts to reproduce data will be favorably received as well. In addition, every paper will be carefully checked for potential plagiarism to guarantee the highest scientific integrity of the journal possible.

Why did I gladly accept Martin's kind invitation to take over the position as Editor-in-Chief of NaunynSchmiedeberg's Archives of Pharmacology without hesitating a moment? I have published 47 papers in the journal since 1989, and with very, very few exceptions, I was always extremely pleased with the rapidity, quality, and fairness of the peer review and publication process. My papers have always become much better as a result of the review process, but the effort to revise a paper was always reasonable. My students, many of whom published their results in NaunynSchmiedeberg's Archives of Pharmacology, were also very happy with the journal. In most cases, publication of my students' papers coincided more or less with the defense of their doctoral theses and, thereby, facilitated their professional careers. Most importantly, I could always openly discuss unresolved and controversial questions and did not have to sell a perfect story (see, e.g., Kinast et al. 2012; Bräunig et al. 2014). Along these lines, I encourage our authors to be very frank and open on limitations of the data and problems in the field. I also like the very flexible format of the journal with no specific limitations to length or number of references. "Science first," academic rigor, and honesty are important characteristics of the journal. The papers by Seifert and Wenzel-Seifert (2002) and Appl et al. (2012) are excellent examples for the formal flexibility of Naunyn-Schmiedeberg's Archives of Pharmacology to accommodate very complex scientific content and to present it clearly. Therefore, it is now time for me to give back to the journal the dedication that my students and I have perceived over almost three decades as authors.

I am also delighted about the reception of my papers published in the journal by the scientific community. In fact, my most-cited publication, a review on constitutive GPCR activity (Seifert and Wenzel-Seifert 2002), has been cited 356 times so far. And several of my original publications from various areas (including papers with "negative" data) published in the journal have also been cited fairly often (see, e.g., Burde et al. 1989; Seifert et al. 1989; Ervens et al. 1991; Appl et al. 2012; Beermann et al. 2012). A recently published meeting report (Heifetz et al. 2015) reached more than 900 downloads within 4 months.

I will follow the path of Martin and encourage submission of high-quality papers from every field of experimental pharmacology. I will also welcome concise reviews on defined drug targets such as a specific GPCR, enzyme or ion channel, orphan drugs constituting an as yet almost completely unchartered territory. I myself plan to submit to the journal a review on a poorly studied drug target, adenylyl cyclase 9 (Werner et al. 2016a, b). Suggestions for themed issues (see, e.g., Gomsyan and Szallasi 2015; Hsu et al. 2015) or meeting reports (see, e.g., Heifetz et al. 2015; Friebe et al. 2015; Schneider and Seifert 2015) are appreciated as well. Moreover, I could envisage publishing issues that focus on the pharmacological achievements of a particular country or geographical region. As a new section for the journal, I will introduce book reviews on pharmacology. Suggestions for books to be considered in this section are appreciated and should be directed to me.

So to conclude, why should you send your top papers to Naunyn-Schmiedeberg's Archives of Pharmacology? Together with the distinguished Editorial Board and Editorial Advisory Board, I will ensure a rapid and fair review process of your best papers from every field of experimental pharmacology. You can rest assured that I will not be biased towards perceived trendy or hot topics, but I am certainly biased towards 
rigorous science. Authors will enjoy a flexible publication format with minimal constraints to put science at the center stage. In view of the data reproducibility crisis (Kannt and Wieland 2016), it will become increasingly important that important data be either confirmed or disputed. Papers addressing both directions will be considered. The journal will also continue to be a platform for discussing important papers in the form of editorials or debates, be it papers published in Naunyn-Schmiedeberg's Archives of Pharmacology or elsewhere (see, e.g., Seifert 2014, 2015a; Gao and Vanhoutte 2014; Schneider et al. 2015). Please do not hesitate to contact me if you have a specific publication project for NaunynSchmiedeberg's Archives of Pharmacology in mind or would like to obtain my advice on a paper that does not exactly fits to traditional foci of the journals such as toxicological themes with a mechanistic thrust. I look forward to productively working with the Editorial Board, the Editorial Advisory Board, our authors, and the publisher Springer-Nature to further strengthen the role of Naunyn-Schmiedeberg's Archives of Pharmacology as an important pharmacological journal.

\section{References}

Appl H, Holzammer T, Dove S, Haen E, Strasser A, Seifert R (2012) Interactions of recombinant human histamine $\mathrm{H}_{1} \mathrm{R}, \mathrm{H}_{2} \mathrm{R}, \mathrm{H}_{3} \mathrm{R}$, and $\mathrm{H}_{4} \mathrm{R}$ receptors with 34 antidepressants and antipsychotics. Naunyn Schmiedeberg's Arch Pharmacol 385:145-170

Ashton JC, Zheng Y, Darlington C, Baek JH, Smith PF (2014) Cannabinoid $\mathrm{CB} 2$ receptor immunolabelling in the healthy brain - still a live possibility. Naunyn Schmiedeberg's Arch Pharmacol 387:301

Beermann S, Seifert R, Neumann D (2012) Commercially available antibodies against human and murine histamine $\mathrm{H}_{4}$-receptor lack specificity. Naunyn Schmiedeberg's Arch Pharmacol 385:125-135

Böhmer T, Pfeiffer N, Gericke A (2014) Three commercial antibodies against $\alpha_{1}$-adrenergic receptor subtypes lack specificity in paraffinembedded sections of murine tissues. Naunyn Schmiedeberg's Arch Pharmacol 387:703-706

Bräunig JH, Albrecht-Küpper B, Seifert R (2014) Adenylyl cyclase regulation in heart failure due to myocardial infarction in rats. Naunyn Schmiedeberg's Arch Pharmacol 387:389-398

Burde R, Seifert R, Buschauer A, Schultz G (1989) Histamine inhibits activation of human neutrophils and HL-60 leukemic cells via $\mathrm{H}_{2}-$ receptors. Naunyn Schmiedeberg's Arch Pharmacol 340:671-678

Cécyre B, Thomas S, Ptito M, Casanova C, Bouchard JF (2014) Evaluation of the specificity of antibodies raised against cannabinoid receptor type 2 in the mouse retina. Naunyn Schmiedeberg's Arch Pharmacol 387:175-184

Cernecka H, Pradidarcheep W, Lamers WH, Schmidt M, Michel MC (2014) Rat $\beta_{3}$-adrenoceptor protein expression: antibody validation and distribution in rat gastrointestinal and urogenital tissues. Naunyn Schmiedeberg's Arch Pharmacol 387:1117-1127

Cheng HB, Bo Y, Shen WX, Ren XG, Tan JN, Jia ZR, Xu CL (2015) Longikaurin $\mathrm{E}$ induces apoptosis of pancreatic cancer cells via modulation of the p38 and PI3K/AKT pathways by ROS. Naunyn Schmiedeberg's Arch Pharmacol 388:623-634

Ervens J, Schultz G, Seifert R (1991) Differential inhibition and potentiation of chemoattractant-induced superoxide formation in human neutrophils by the cell-permeant analogue of cGMP, $\mathrm{N}^{2}, 2^{\prime}-O$ dibutyryl guanosine $3^{\prime}: 5$ '-cyclic monophosphate. Naunyn Schmiedeberg's Arch Pharmacol 343:370-376

Friebe A, Sandner P, Seifert R (2015) From bedside to bench — meeting report of the 7th International Conference on cGMP "cGMP: generators, effectors and therapeutic implications" in Trier, Germany, from June 19th to 21st 2015. Naunyn Schmiedeberg's Arch Pharmacol 388:1237-1246

Gao Y, Vanhoutte PM (2014) Tissues cIMPly do not lie. Naunyn Schmiedeberg's Arch Pharmacol 387:901-903

Gille A, Seifert R (2004) Xanthine nucleotide-specific G-protein $\alpha$ subunits: a novel approach for the analysis of G-proteinmediated signal transduction. Naunyn Schmiedeberg's Arch Pharmacol 369:141-150

Gomsyan A, Szallasi A (2015) Targeting TRP channels: beyond TRPV1. Naunyn Schmiedeberg's Arch Pharmacol 388:387-388

Heifetz A, Schertler GF, Seifert R, Tate CG, Sexton PM, Gurevich VV, Fourmy D, Cherezov V, Marshall FH, Storer RI, Moraes I, Tikhonova IG, Tautermann CS, Hunt P, Ceska T, Hodgson S, Bodkin MJ, Singh S, Law RJ, Biggin PC (2015) GPCR structure, function, drug discovery and crystallography: report from academiaindustry international conference (UK Royal Society) Chicheley Hall, 1-2 September 2014. Naunyn Schmiedeberg's Arch Pharmacol 388:883-903

Hsu T, Steeg PS, Zollo M, Wieland T (2015) Progress on Nme (NDP kinase/Nm23/Awd) gene family-related functions derived from animal model systems: studies on development, cardiovascular disease, and cancer metastasis exemplified. Naunyn Schmiedeberg's Arch Pharmacol 388:109-117

Imeri F, Blanchard O, Jenni A, Schwalm S, Wünsche C, Zivkovic A, Stark H, Pfeilschifter J, Huwiler A (2015) FTY720 and two novel butterfly derivatives exert a general anti-inflammatory potential by reducing immune cell adhesion to endothelial cells through activation of S1P 3 and phosphoinositide 3-kinase. Naunyn Schmiedeberg's Arch Pharmacol 388:1283-1292

Kannt A, Wieland T (2016) Managing risks in drug discovery: reproducibility of published findings. Naunyn Schmiedeberg's Arch Pharmacol 389:353-360

Kinast L, von der Ohe J, Burhenne H, Seifert R (2012) Impairment of adenylyl cyclase 2 function and expression in hypoxanthine phosphoribosyltransferase-deficient rat B103 neuroblastoma cells as model for Lesch-Nyhan disease: BODIPY-forskolin as pharmacological tool. Naunyn Schmiedeberg's Arch Pharmacol 385:671-683

Laue S, Winterhoff M, Kaever V, van den Heuvel JJ, Russel FG, Seifert R (2014) cCMP is a substrate for MRP5. Naunyn Schmiedeberg's Arch Pharmacol 387:893-895

Merzoug S, Toumi ML, Tahraoui A (2014) Quercetin mitigates adriamycin-induced anxiety- and depression-like behaviors, immune dysfunction, and brain oxidative stress in rats. Naunyn Schmiedeberg's Arch Pharmacol 387:921-933

Michel MC (2014) How significant are your data? The need for a culture shift. Naunyn Schmiedeberg's Arch Pharmacol 387:1015-1016

Michel MC, König G, Mohr K, Simmet T (2005) Editorial guidelines for manuscripts on the pharmacology of plant extracts. Naunyn Schmiedeberg's Arch Pharmacol 371:349-350

Michel MC, Mayoux E, Vallon V (2015a) A comprehensive review of the pharmacodynamics of the SGLT2 inhibitor empagliflozin in animals and humans. Naunyn Schmiedeberg's Arch Pharmacol 388:801-816

Michel MC, Chess-Williams R, Hegde SS (2015b) Are blood vessels a target to treat lower urinary tract dysfunction? Naunyn Schmiedeberg's Arch Pharmacol 388:687-694

Michel-Reher MB, Michel MC (2015) Regulation of GAPDH expression by treatment with the $\beta$-adrenoceptor agonist isoprenaline-is GAPDH a suitable loading control in immunoblot experiments? Naunyn Schmiedeberg's Arch Pharmacol 388:1119-1120 
Modjtahedi H, Cho BC, Michel MC, Solca F (2014) A comprehensive review of the preclinical efficacy profile of the ErbB family blocker afatinib in cancer. Naunyn Schmiedeberg's Arch Pharmacol 387: $505-521$

Motulsky HJ (2014a) Common misconceptions about data analysis and statistics. Naunyn Schmiedeberg's Arch Pharmacol 387:1017-1023

Motulsky HJ (2014b) Different degree of heart failure. Naunyn Schmiedeberg's Arch Pharmacol 387:599

Reinartz MT, Kälble S, Littmann T, Ozawa T, Dove S, Kaever V, Wainer IW, Seifert R (2015a) Structure-bias relationships for fenoterol stereoisomers in six molecular and cellular assays at the $\beta_{2-}$ adrenoceptor. Naunyn Schmiedeberg's Arch Pharmacol 388:51-65

Reinartz MT, Kälble S, Wainer IW, Seifert R (2015b) Interaction of fenoterol stereoisomers with $\beta_{2}$-adrenoceptor- $\mathrm{G}_{\mathrm{s} \alpha}$ fusion proteins: antagonist and agonist competition binding. Naunyn Schmiedeberg's Arch Pharmacol 388:517-524

Schneider EH, Seifert R (2015) Report on the third symposium "cCMP and cUMP as new second messengers". Naunyn Schmiedeberg's Arch Pharmacol 388:1-3

Schneider EH, Neumann D, Seifert R (2015) Histamine $\mathrm{H}_{4}$-receptor expression in the brain? Naunyn Schmiedeberg's Arch Pharmacol 388:5-9

Seifert R (2014) Is cIMP a second messenger with functions opposite to those of cGMP? Naunyn Schmiedeberg's Arch Pharmacol 387: 897-899

Seifert R (2015a) How do basic secretagogues activate mast cells? Naunyn Schmiedeberg's Arch Pharmacol 388:279-281

Seifert R (2015b) cCMP and cUMP: emerging second messengers. Trends Biochem Sci 40:8-15

Seifert R, Wenzel-Seifert K (2002) Constitutive activity of G-proteincoupled receptors: cause of disease and common property of wildtype receptors. Naunyn Schmiedeberg's Arch Pharmacol 366:381-416
Seifert R, Burde R, Schultz G (1989) Lack of opioid peptides, morphine and naloxone on superoxide formation in human neutrophils and HL-60 leukemic cells. Naunyn Schmiedeberg's Arch Pharmacol 340:101-106

Seifert R, Lushington GH, Mou TC, Gille A, Sprang SR (2012) Inhibitors of membranous adenylyl cyclases. Trends Pharmacol Sci 33:64-78

Starke K (1998) A history of Naunyn-Schmiedeberg's Archives of Pharmacology. Naunyn Schmiedeberg's Arch Pharmacol 385:1-109

Strasser A, Wittmann HJ, Schneider EH, Seifert R (2015) Modulation of GPCRs by monovalent cations and anions. Naunyn Schmiedeberg's Arch Pharmacol 388:363-380

Tripathi A, Gaponenko V, Majetschak M (2016) Commercially available antibodies directed against $\alpha$-adrenergic receptor subtypes and other $G$ protein-coupled receptors with acceptable selectivity in flow cytometry experiments. Naunyn Schmiedeberg's Arch Pharmacol 389: 243-248

Werner K, Kälble S, Wolter S, Schneider EH, Buschauer A, Neumann D, Seifert R (2016a) Flow cytometric analysis with a fluorescently labeled formyl peptide receptor ligand as a new method to study the pharmacological profile of the histamine $\mathrm{H}_{2}$ receptor. Naunyn Schmiedeberg's Arch Pharmacol 388:1039-1052

Werner K, Neumann D, Seifert R (2016b) High constitutive Akt2 activity in U937 promonocytes: effective reduction of Akt 2 phosphorylation by the histamine $\mathrm{H}_{2}$-receptor and $\beta_{2}$-adrenergic receptor. Naunyn Schmiedeberg's Arch Pharmacol 389:87-101

Wolter S, Dove S, Golombek M, Schwede F, Seifert R (2014) N ${ }^{4}$ Monobutyryl-cCMP activates PKA RI $\alpha$ and PKA RII $\alpha$ more potently and with higher efficacy than PKG I $\alpha$ in vitro but not in vivo. Naunyn Schmiedeberg's Arch Pharmacol 387:1163-1175 